\title{
ETHNIC CHINESE NETWORKS \\ IN INTERNATIONAL TRADE
}

James E. Rauch

Vitor Trindade

Working Paper 7189

http://www.nber.org/papers/w7189

\section{NATIONAL BUREAU OF ECONOMIC RESEARCH \\ 1050 Massachusetts Avenue \\ Cambridge, MA 02138 \\ June 1999}

We would like to thank Alessandra Casella, John McMillan, and Chris Woodruff for helpful comments and Neville Francis for excellent research assistance. Previous versions of this paper were presented at the U. S. International Trade Commission APEC Symposium, the UCSD Conference on "Cooperation Under Difficult Conditions," and the Sloan Projects Globalization Conference. Financial support was provided by NSF grant \#SBR-9709237 (Rauch). All opinions expressed are those of the authors and not those of the National Bureau of Economic Research.

(C) 1999 by James E. Rauch and Vitor Trindade. All rights reserved. Short sections of text, not to exceed two paragraphs, may be quoted without explicit permission provided that full credit, including $(\mathrm{C}$ notice, is given to the source. 
Ethnic Chinese Networks in International Trade

James E. Rauch and Vitor Trindade

NBER Working Paper No. 7189

June 1999

\begin{abstract}
Ethnic Chinese networks, as proxied by the product of ethnic Chinese population shares, are found in 1980 and 1990 to have increased bilateral trade both within Southeast Asia and for other country pairs. Their effects within Southeast Asia are much greater for differentiated than for homogeneous products, while for other country pairs their effects are neither economically nor statistically significantly different across commodity groups. We interpret these and other, complementary findings as showing that (1) where ethnic Chinese communities are relatively large fractions of their countries' populations and have relatively numerous direct connections across international borders, they facilitate international trade primarily by helping to match international buyers and sellers in characteristics space, and (2) ethnic Chinese communities that are small fractions of their countries' populations are close-knit and facilitate international trade mainly by enforcing community sanctions that deter opportunistic behavior. The smallest estimated increase in bilateral trade in differentiated products within Southeast Asia attributable to ethnic Chinese networks exceeds 150 percent, suggesting that the informal trade barriers these networks help to overcome are economically important.
\end{abstract}

James E. Rauch

Department of Economics

University of California, San Diego

La Jolla, CA 92093

and NBER

jrauch@weber.ucsd.edu
Vitor Trindade

Department of Economics

University of California, San Diego

La Jolla, CA 92093

vtrindad@weber.ucsd.edu 


\section{Introduction}

The importance of business and social networks in overcoming informal barriers to international trade is being increasingly recognized, both in empirical work (Gould 1994, Head and Ries 1999) and theoretical work (Greif 1993, Rauch and Casella 1998). Informal trade barriers may consist of inadequate information about international trading opportunities or weak international legal institutions. Such barriers, in turn, are leading candidates to help explain "the mystery of the missing trade" (Trefler 1995) or the home bias in international trade found by McCallum (1995) and many others (e.g., Helliwell 1998).

Among the many types of business and social networks that exist, coethnic networks have the advantage for empirical research that it is much easier to identify network members. ${ }^{1}$ Of coethnic networks active in international trade, the Overseas Chinese have received the most attention (see, e.g., Redding 1995). Studies show that not only the Overseas Chinese but also many other ethnic groups living outside their countries of origin create formal or informal associations to which coethnic businesspeople from both the host countries and the mother country have access. ${ }^{2}$ These associations serve as nodes for information exchange. In this sense

${ }^{1}$ Census takers will not record the characteristic "former employee of IBM", yet the fact that many of the key decision makers in the hard disk drive industry shared this characteristic contributed to the rapid spread of popularity of Singapore as a site for FDI, according to industry observers (McKendrick 1998).

${ }^{2}$ The Overseas Chinese, however, have been exceptional in this regard. Freedman (1967, p. 17) states, "The society built up by the Overseas Chinese in Southeast Asia has always been remarkable for its wealth of voluntary associations." Lever-Tracy, Ip, and Tracy (1996) report (p. 104), "Chew Choo Keng of Singapore remembered how 'It was through my friends at the clubs that I was able to expand my businesses into Thailand, Malaya, Burma and Indonesia'." Unfortunately, the reasons why some ethnic groups form successful associations and others do not are still a mystery. 
the ethnic Chinese are best seen as forming a set of interlinked national networks rather than a unified international network, though since 1991 the international links have become more formalized and perhaps strengthened through biennial meetings of the World Chinese Entrepreneurs Convention. ${ }^{3}$

We will mainly address two issues in this paper. First, by what mechanism(s) do coethnic networks overcome informal barriers to international trade? Provision of information regarding trading opportunities suggests different lessons for policy makers than does the mechanism of deterring opportunistic behavior through enforcement of community sanctions. Second, what is the quantitative importance for trade of what is probably the world's largest and most internationally dispersed set of interlinked business and social networks? The answer is of interest in its own right, and also because it implicitly provides a lower bound on the tradereducing impact of informal barriers.

In the next section of this paper we present our strategy for identifying the means through which ethnic Chinese networks overcome informal barriers to international trade. In section III we specify our empirical model and describe our data. We present our results in section IV and check their robustness to some changes in sample and specification. In our concluding section we briefly discuss what guidance our results could furnish for the formulation of policy.

\section{Theoretical Framework}

We study the impact of ethnic Chinese networks on bilateral trade. Following the lead of

${ }^{3}$ Recently Singapore was chosen as the venue for the first permanent secretariat of the Convention (Leong 1999). 
Gould (1994) and Rauch and Casella (1998), we hypothesize that ethnic Chinese networks promote bilateral trade primarily by providing market information and by supplying matching and referral services, for example helping producers find the right distributors for their consumer goods or assemblers find the right suppliers for their components. This is consistent with the descriptive literature. Kotkin (1992, p. 169) states that "Chinese entrepreneurs remain, in essence, arbitrageurs, their widespread dispersion a critical means of identifying prime business opportunities." Weidenbaum and Hughes (1996, p. 55) write:

the members of the bamboo network operate in the interstices of the trading world. They make components, manufacture for others, and perform subassembly work. They are also heavily involved in wholesaling, financing, sourcing, and transporting....The leading businessmen know each other personally and do deals together, with information spreading through an informal network rather than through more conventional channels.

At the same time we recognize that ethnic Chinese networks may promote international trade through other mechanisms. Greif $(1989,1993)$ has shown that coethnic networks can provide community enforcement of sanctions that deter opportunistic behavior in a weak international legal environment. This is also consistent with descriptions of the operation of ethnic Chinese networks. Weidenbaum and Hughes (1996, p. 51) report, "If a business owner violates an agreement, he is blacklisted. This is far worse than being sued, because the entire Chinese network will refrain from doing business with the guilty party."

Building on Rauch (1999), we will attempt to distinguish these two hypotheses by estimating separately the impacts of ethnic Chinese networks on bilateral trade in commodities that have "reference prices" and commodities that do not. A reference price is defined as a price that is quoted without mentioning a brand name or other producer identification. Commodities 
that possess reference prices are taken to be sufficiently homogeneous that if traders see the price differential between two countries' markets is large enough to cover customs and transport costs, they know it is profitable to ship the product. Commodities that do not possess reference prices are taken to be sufficiently differentiated that prices cannot convey all the information relevant for international trade: buyers and sellers must be matched in characteristics space, and hence the thicker information that can be provided by ethnic Chinese networks is much more important than for international trade in homogeneous commodities. Again following Rauch (1999), we will further divide homogeneous commodities into commodities whose reference prices are quoted on organized exchanges such as the London Metal Exchange and those whose reference prices are quoted only in trade publications such as Chemical Marketing Reporter. The reason to treat commodities traded on organized exchanges differently from other homogeneous commodities is that we know the former have specialized traders that can keep informed of their prices around the globe and perform international commodity arbitrage while the same is only potentially true for the latter.

In contrast, the threat of community sanctions should deter equally shipments of debased metals, rotting fruit, or stockings with runs. The same lack of distinction between commodities with and commodities without reference prices should hold for other forms of opportunistic behavior such as failure to pay for a shipment one has received. In short, we argue that the tradepromoting effect of ethnic Chinese networks through the mechanism of community enforcement of sanctions is equal across commodity groups. ${ }^{4}$

${ }^{4}$ Certain private institutions have evolved to fill the void left by the weak international legal framework. Letters of credit allow the trading parties to shift some of their commercial credit risk to the issuing bank and allow the buyer to defer payment until the shipment passes quality 
Should we observe a larger positive effect of ethnic Chinese networks on bilateral trade in commodities without reference prices than in commodities with them, corroborating evidence for our interpretation of this difference can be had by examining the effects on bilateral trade of past colonial relationships. The integration of commercial interests that prevailed during colonial periods should have increased the familiarity of the colonial power with the market in the colony and vice-versa and should have established contacts that make it easier for producers to find the right distributors, assemblers to find the right suppliers, and so on. On the other hand, it is not clear that colonial ties should provide any means of community enforcement of sanctions to deter opportunistic behavior. We thus expect even more strongly than we do for ethnic Chinese networks that colonial ties will increase bilateral trade in differentiated products more than in homogeneous products. If we find such a difference we are thus more confident that the mechanism of market information, matching and referral is driving the same difference in the impacts of ethnic Chinese networks.

In the empirical model below, our proxy for the strength of ethnic Chinese network links between any two countries will be the probability that, if we select an individual at random from each country, both will be ethnic Chinese. We will thus create a variable equal to the product of the two countries' ethnic Chinese population shares. An immediate concern is that, if countries with similar tastes tend to trade differentiated products more with each other (as has been argued

inspection; for more information on their benefits see del Busto (1994). International commercial arbitration offers a private means of dispute resolution; Craig, Park, and Paulsson (1985) is the standard reference for International Chamber of Commerce arbitration. Since these private institutions are means of deterring opportunistic behavior in international trade that can substitute for community enforcement, it is important for our argument that they be equally effective across commodity groups. We know of no reason to doubt this. 
by Linder (1961), for example), one could interpret a finding of a greater effect of the ethnic Chinese variable on bilateral trade in differentiated products as indicating that the variable was a proxy for taste similarity rather than networks. We argue that if this alternative interpretation is correct, common language across countries should also have a greater effect on bilateral trade in differentiated than in homogeneous products, the idea being that common Chinese ancestry should have effects on taste similarity roughly equal to those of common mother tongue (recall that most emigration from China occurred before World War I). With this in mind we will consider the impact of three different measures of common language below. All are based primarily on birth languages rather than linguae francae because these should be the best proxies for taste similarity. ${ }^{5}$

\section{Empirical Model and Data}

\section{A. Gravity model specification}

We examine the effects of ethnic Chinese networks using a standard gravity model of bilateral trade. The gravity model takes its name from the prediction that the volume of trade between two countries will be directly related to the product of their economic masses (as measured by GDP or GNP) and inversely related to the distance between them. Helpman (1987) shows that proportionality of the bilateral volume of trade to the product of the trading partners' GDPs, $V_{i j}=\alpha G D P_{i} G D P_{j}$, can be derived from the assumption that every country consumes its own output and that of every other country in proportion to its share of world demand. We

${ }^{5}$ For example, all of our common language variables yield high values for the country pair Austria-Germany and low values for the country pair Kenya-United Kingdom. 
follow Rauch (1999) in viewing this proportional relationship as a basic "null" or starting point for further analysis of trade rather than as something that itself needs to be explained. ${ }^{6}$

In line with the usual gravity model specification, we assume that factors that aid or resist trade cause deviations from the basic proportional relationship multiplicatively. In addition to distance, we will start with the other factors aiding or resisting trade that were used by Frankel and co-authors in a series of papers synthesized in Frankel (1997). Per capita income has become a standard covariate in gravity models (for example, it is used in the paper by Eaton and Tamura (1994) cited below), and Frankel included the product of the two countries' per capita GNPs. (He also used GNP rather than GDP as his measure of a country's economic mass.) He added a dummy variable indicating when two countries are adjacent, which is important since the distance between Chicago and Mexico City, say, is a much less complete measure of the physical separation between the United States and Mexico than is the distance between Chicago and London of the physical separation between the United States and the United Kingdom. Frankel completed his basic specification with a dummy variable indicating the presence of either a common language or past colonial relationship between two countries. To this set of five explanatory variables (product of GNPs, product of per capita GNPs, distance, adjacency, and common language/colonial tie), Frankel (1997, Chapter 4) added various lists of dummy variables indicating membership in existing and potential trading blocs.

For the reasons given in the previous section, we will modify the basic gravity model specification used by Frankel to include separate variables for common language and colonial

${ }^{6}$ Deardorff (1998, p. 12) states, "any plausible model of trade would yield something very like the gravity equation, whose empirical success is therefore not evidence of anything, but just a fact of life." 
ties. Following Deardorff (1998) and Wei (1996), we also include a variable for the geographical remoteness of the trading partners from the rest of the world. Their argument is that, all else equal, two countries that are very far away from most other large potential trading partners (such as Australia and New Zealand) will trade more with each other than two countries that are close to most other large potential trading partners (such as Denmark and Portugal). We include dummy variables indicating membership in the European Community (EEC) and the European Free Trade Association (EFTA), the two preferential trade areas that in the years covered by our data (1980 and 1990) were both the oldest post-World War II major regional trading arrangements (Frankel 1997, Table 1.1) and the ones most widely believed to have brought about genuine reductions in trade barriers between their members. We conclude our gravity model specification with the addition of the product of ethnic Chinese population shares, our proxy for the strength of ethnic Chinese network links between the trading partners.

Following Rauch (1999) and the discussion in section II, we divide traded commodities into three groups and estimate our gravity model separately for each aggregated group. The three groups are commodities traded on organized exchanges, commodities possessing "reference prices" but not traded on organized exchanges, and all other commodities, which we label as differentiated.

We can now write our gravity model as follows:

$$
\begin{gathered}
V_{i j k}=\alpha_{k}\left(G N P_{i} G N P_{j}\right)^{\beta_{k}}\left(P G N P_{i} P G N P_{j}\right)^{\gamma_{k}} \text { DISTANCE }{ }^{\delta_{k}} \text { REMOTE }^{\varepsilon_{k}} \\
\times \exp \left(\zeta_{k} \text { ADJACENT }+\eta_{k} \text { EEC }+\theta_{k}\right. \text { EFTA } \\
\left.+\lambda_{k} L A N G U A G E+\varphi_{k} \text { COLOTIE }+\psi_{k} \text { CHINPOP }+u_{i j k}\right), \quad k=1,2,3,
\end{gathered}
$$

where 
$k=1$ denotes the organized exchange commodity group, $k=2$ denotes the reference priced commodity group, and $k=3$ denotes the differentiated commodity group;

$V_{i j k}$ denotes bilateral nominal value of trade (exports plus imports) between countries $i$ and $j$ in commodity group $k$;

GNP denotes nominal GNP;

PGNP denotes per capita nominal GNP;

$D I S T A N C E$ equals the great circle distance between the principal cities of countries $i$ and $j$;

REMOTE equals the product of the weighted sum of country $i$ 's distances from all other countries in the sample and the same weighted sum for country $j$, where the weights are the GNPs of the other countries;

$A D J A C E N T$ equals one if countries $i$ and $j$ share a land border and zero otherwise;

EEC or EFTA equals one if countries $i$ and $j$ are members of the European Community or European Free Trade Association, respectively, and zero otherwise;

$L A N G U A G E$ is one of three measures, described in the next subsection, of the extent to which countries $i$ and $j$ share birth languages;

COLOTIE takes the value of one if countries $i$ and $j$ share a colonial tie and zero otherwise;

CHINPOP equals the product of the ethnic Chinese population shares for countries $i$ and $j$;

$u_{i j k}$ is a Gaussian white noise error term associated with the dependent variable $V_{i j k}{ }^{7}$

The dependent variable $V_{i j k}$ is bounded below by zero, and some observations achieve this bound. Following Eaton and Tamura (1994), we estimate a modified gravity model in which the right-hand side of equation (1) must achieve a minimum threshold value $a_{k}$ before strictly positive values of $V_{i j k}$ occur. In the iceberg transportation cost metaphor, we might think of $-a_{k}$ as an amount of "melting" that occurs as soon as the trip starts, independent of the distance traveled.

\footnotetext{
${ }^{7}$ The reader might note that it is possible to rewrite equation (1), replacing the product of per capita GNPs with the product of populations, in which case the exponent on the product of GNPs would equal $\beta_{k}+\gamma_{k}$ and the exponent on the product of populations would equal $-\gamma_{k}$.
} 
The gravity model to be estimated in section IV below is then

$$
\begin{gathered}
V_{i j k}=\max \left[-a_{k}+\alpha_{k}\left(G N P_{i} G N P_{j}\right)^{\beta_{k}}\left(P G N P_{i} P G N P_{j}\right)^{\gamma_{k}} \text { DISTANCE }{ }^{\delta_{k}} R_{E M O T E} \varepsilon_{k}\right. \\
\quad \times \exp \left(\zeta_{k} \text { ADJACENT }+\eta_{k} \text { EEC }+\theta_{k}\right. \text { EFTA } \\
\left.\left.+\lambda_{k} \text { LANGUAGE }+\varphi_{k} \text { COLOTIE }+\psi_{k} \text { CHINPOP }+u_{i j k}\right), 0\right], \quad k=1,2,3 .
\end{gathered}
$$

Rearranging and taking natural logarithms of both sides yields

$$
\begin{aligned}
\ln \left(a_{k}+V_{i j k}\right)= & \max \left[\ln \alpha_{k}+\beta_{k} \ln \left(G N P_{i} G N P_{j}\right)+\gamma_{k} \ln \left(P G N P_{i} P G N P_{j}\right)+\delta_{k} \ln \right. \text { DISTANCE } \\
& +\varepsilon_{k} \ln R E M O T E+\zeta_{k} A D J A C E N T+\eta_{k} E E C+\theta_{k} E F T A \\
+ & \left.\lambda_{k} L A N G U A G E+\varphi_{k} \text { COLOTIE }+\psi_{k} \text { CHINPOP }+u_{i j k}, \ln a_{k}\right], \quad k=1,2,3 .
\end{aligned}
$$

Each of equations (3) will be estimated by maximum likelihood, where the likelihood function is constructed using what we call a threshold Tobit model. The details of the estimation procedure are given in Eaton and Tamura (1994, pp. 490-492).

We estimate equations (3) separately for the two years in which we have data on ethnic Chinese populations (1980 and 1990) in order to check that our results are not the artifact of a particular time period and to allow for changes in coefficients that might have taken place due (for example) to improvements in communication and transportation technology or in international legal institutions. In light of the theory presented so far, in each of the two years we expect to find $\psi_{3}>\psi_{2}$ and $\psi_{3}>\psi_{1}$. Though our main hypothesis concerns the distinction between differentiated and homogeneous commodities, we might also expect $\psi_{2}>\psi_{1}$ : the effects of CHINPOP for reference priced commodities will be in between those for differentiated commodities and commodities traded on organized exchanges because, with regard to matching international buyers and sellers, their homogeneity makes them like organized exchange commodities but their lack of organized exchanges makes them like differentiated commodities. 
If we observe $\psi_{1}>0$, it could indicate that organized exchanges cannot fully substitute for business and social networks in matching international buyers and sellers or that ethnic Chinese networks also promote trade by deterring opportunistic behavior. We will discuss the possibility that ethnic Chinese networks promote bilateral trade through both mechanisms further in section IV. Suppose we do in fact observe the expected rankings of the coefficients $\psi_{k}$. Our interpretation that this indicates that the product of ethnic Chinese population shares measures networks that provide market information and facilitate the matching of international buyers and sellers in characteristics space is weakened if the same rankings across commodity groups are observed for the coefficients $\lambda_{k}$ on the common language variable (which argues for a taste similarity interpretation); our interpretation is reinforced if the same rankings are observed for the coefficients $\varphi_{k}$ on the colonial ties dummy (which argues for a business contact interpretation).

\section{B. Data}

The sample of countries used in the estimation below is listed in Table 1. They are the same 63 countries that were chosen by Frankel (1997). This allows us to use his data for GNP and per capita GNP (in current dollars), great circle distance between principal cities, and dummies for adjacency, European Community membership, and European Free Trade Association membership. A colonial ties dummy variable was constructed on the basis of articles in the Encyclopedia Britannica (1997). We were able to find two sources of data on ethnic Chinese population that covered most of the countries in our sample. Data on ethnic Chinese population circa 1980 was collected from Poston and $\mathrm{Yu}$ (1990). The same data circa 1990 was collected from the Overseas Chinese Economy Yearbook 1990 (1991). Table 1 lists 
the number of ethnic Chinese (column CHIN) and the overall population (column POP) for 1980 and 1990 for all countries in our sample for which this data is available.

The simplest of our three different measures of common language is a dummy variable constructed on the basis of country articles in the Encyclopedia Britannica, which list major languages spoken in each country. This variable takes the value one if at least ten percent of the populations in countries $i$ and $j$ share one common native language, and zero otherwise. The other two common language variables, one that we constructed and one constructed by Boisso and Ferrantino (1997), are both continuous and are constructed in a similar manner but do not use the same sources. To construct our variable, for each country we started with estimates from Ethnologue Index (Grimes 1992) of the number of mother tongue speakers of each of the various languages. We then divided these estimates by the midyear population estimates for the corresponding years in the United Nations Demographic Yearbook. If the year for the estimates of native speakers was not specified in Ethnologue Index, we used the 1990 population estimates in the Yearbook. We thus obtained language shares $s_{i l}$ for each country $i$ and language $l$ (not counting languages only spoken in one country). We then calculated our measure of common language between countries $i$ and $j$ using the formula $\sum_{l} s_{i l} s_{j l}$. Note that our variable equals

one for a pair of countries for which 100 percent of the populations share one language and zero for a pair of countries between which no two people share a language. Essentially the same formula but a completely different source was used by Boisso and Ferrantino (1997) to construct 
their common language variable. ${ }^{8}$

Unlike Frankel (1997), we use the World Trade Database (WTDB) of Statistics Canada as our source for bilateral trade (see Feenstra, Lipsey, and Bowen 1997 for a description of the WTDB). The WTDB is derived from the United Nations COMTRADE data used by Frankel. Aside from cost and convenience (the NBER has made the WTDB available on CD-ROM), the importance of which should not be underestimated given that data at the four-digit SITC level are being used, the main advantage of the WTDB over the COMTRADE data is that special care was taken to insure that trading partners were correctly identified (as opposed to listing an entrepôt as the trading partner), mainly by making careful efforts to insure that exports of country $i$ to country $j$ of commodity $x$ equal imports of country $j$ from country $i$ of commodity $x$.

As discussed in the previous subsection, traded commodities are classified into three categories: organized exchange, reference priced, and differentiated, at the three- and four-digit SITC level. Trade reported at a less disaggregated level was omitted. Fortunately, this accounted for only 0.1 percent of the total value of trade in our sample in each of the two years. Commodities were classified in the following manner. All commodities at the five-digit SITC level were classified by looking them up in International Commodity Markets Handbook and The Knight-Ridder CRB Commodity Yearbook (to check for organized exchanges) and Commodity Prices (to check for reference prices, e.g., price quotations published in industry journals).

${ }^{8}$ Boisso and Ferrantino describe the construction of their common language variable on pp. 464465 of their paper. Unlike our variable, theirs gives some weight to linguae francae and is a measure of linguistic dissimilarity computed as one minus the formula we use. For the sake of comparability we multiplied by minus one and added one before using their variable, and we also filled in values for two countries present in our sample but missing from theirs, Libya and Taiwan, with the country-pair values for Tunisia and China, respectively. 
Classification of the next higher level of aggregation was then done according to which of the three categories accounted for the largest share (almost always more than half) of the value of its world trade. Since the WTDB does not report world trade by five-digit SITC, the sum of 1980 U.S. General Imports and Exports from the U.S. Department of Commerce was used for this purpose. Because ambiguities arose that were sometimes sufficiently important to affect the classification at the three- or four-digit level, both "conservative" and "liberal" classifications were made, with the former minimizing the number of three- and four-digit commodities that are classified as either organized exchange or reference priced and the latter maximizing those numbers. An appendix listing all of the commodities used in the estimation below and their conservative and liberal classifications is available on request.

\section{Results of Estimation}

Tables 2 and 3 give estimates of equations (3) for 1980 and 1990, respectively. It should be noted that no attempt was made to adjust for changes in classification of commodities by the three categories that may have occurred during the period 1980-1990. Ethnic Chinese population data are not available for six countries in 1980 and five countries in 1990, reducing the maximum number of observations from $(63)(62) / 2=1953$ to $(57)(56) / 2=1596$ and $(58)(57) / 2=1653$, respectively. Below we will check the robustness of our results to inclusion of the omitted countries on the assumption that their ethnic Chinese populations are zero. We also omitted trade between China and Taiwan because of the special barriers to trade that exist between them, ${ }^{9}$

${ }^{9}$ Direct trade between China and Taiwan is illegal. The WTDB does not report any trade between China and Taiwan in 1980 but reports positive trade between them in 1990, reflecting the relaxation of restrictions on indirect trade through Hong Kong that began in the mid-1980s. 
reducing the number of observations to 1595 in 1980 and 1652 in 1990. Because some trade between China and Taiwan that passes through Hong Kong may be incorrectly counted as ChinaHong Kong or Hong Kong-Taiwan trade, below we will consider the robustness of our results to omission of these two country pairs.

In Tables 2 and 3 and all subsequent tables we report only results using the continuous common language variable that we constructed. In 1980 none of the three common language variables was significant for any commodity group in either aggregation, while in 1990 our continuous common language variable yielded greater log-likelihood values for every commodity group for both aggregations than did the other two common language variables. Since in both years our qualitative results were unaffected by the choice of common language variable, it seemed appropriate to standardize on our continuous common language variable for reporting purposes (results using the other common language variables are available on request).

We see from Tables 2 and 3 that for both years and all commodity classifications the coefficients on the logarithm of the product of GNPs are close to one, and we cannot reject (at the five percent level) the hypothesis that this coefficient equals one for any commodity classification in 1990 or for the organized exchange commodity groups or the liberally aggregated reference price commodity group in 1980 . This result is consistent with the proportionality between bilateral trade and the product of GNPs predicted by the gravity model. The coefficients on the logarithms of the product of per capita GNPs, DISTANCE, and REMOTE always have the expected signs and are always significant, usually highly so. The estimated thresholds are always positive and highly significant. The coefficients on ADJACENT are always positive, but not significant for the organized exchange commodity groups in 1980 or the 
liberally aggregated reference price commodity group in 1980 . The coefficients on EEC and EFTA are almost always insignificant, the exceptions being the liberally aggregated organized exchange commodities in 1980 (EEC negative and significant) and the differentiated commodity groups in 1980 (EFTA positive and significant). The results for EFTA are consistent with the findings of Frankel (1997, p. 86), but Frankel (p. 83) found that the EEC dummy became positive and significant in 1990 after being insignificant in 1980 and earlier.

Turning to the coefficients of interest, we first note that the coefficients on CHINPOP are positive and highly significant for differentiated products for both years and for both the conservative and liberal aggregations. Second, we observe that the coefficients on CHINPOP are largest for the differentiated commodity group and smallest for the organized exchange commodity group for both years and for both the conservative and liberal aggregations. (We will address the economic and statistical significance of the differences across commodity groups below.) Third, we note that the coefficients on $L A N G U A G E$ are not statistically significant for the differentiated product group in any year and in any aggregation (and the point estimates of these coefficients are smallest for this group for both years in both aggregations), while they are positive and significant for the organized exchange and reference priced product groups in 1990 for both aggregations. Finally, we observe that the coefficients on COLOTIE are always largest for the differentiated commodity group and smallest for the organized exchange commodity group except for the liberal aggregation in 1990, where the coefficient on COLOTIE is smallest for the reference priced commodity group. (We will discuss the statistical significance of the differences across commodity groups below.) At first glance, then, the results reported in Tables 2 and 3 appear very supportive of our hypothesis that ethnic Chinese networks promote bilateral 
trade by providing market information and facilitating matching of international buyers and sellers in characteristics space. The results for LANGUAGE and COLOTIE support our interpretation of the product of ethnic Chinese population shares as a measure of networks of business contacts rather than taste similarity.

There is a theoretical and a related technical reason to be dissatisfied with the estimates of the coefficients on CHINPOP in Tables 2 and 3, however. Theoretically, we might expect ethnic Chinese networks to behave differently within Southeast Asia than for other country pairs. The ethnic Chinese are typically much larger fractions of the total populations in Southeast Asian countries (indeed, they are the majority in China, Hong Kong, Singapore, and Taiwan), and their direct transnational personal ties are more numerous within Southeast Asia. We can thus expect, on the one hand, that the ethnic Chinese within Southeast Asia will occupy a much more diverse range of business niches and be better able to provide market information and matching and referral services across international borders, but on the other hand we can expect ethnic Chinese communities outside of Southeast Asia to be more close-knit and share information more thoroughly. It therefore seems advisable to separate Southeast Asian country pairs from all other country pairs when estimating the coefficient on CHINPOP. There is also a technical reason for doing so: the average probability that two randomly selected individuals will both be ethnic Chinese is roughly 20 percent for Southeast Asian country pairs but only about 0.02 percent for all other country pairs, a difference of three orders of magnitude. ${ }^{10}$ The estimation routine may

\footnotetext{
${ }^{10}$ The Southeast Asian countries in our sample are China, Hong Kong, Indonesia, Malaysia, the Philippines, Singapore, Taiwan, and Thailand. In 1980 and 1990 the mean values of CHINPOP for Southeast Asian country pairs (less China-Taiwan) are 0.210 and 0.198 , respectively, while the mean values of CHINPOP for all other country pairs are 0.000163 and 0.000270 .
} 
then treat the observations on CHINPOP for all other country pairs as an undifferentiated mass of zeroes and essentially estimate the coefficient on CHINPOP using the information for Southeast Asian country pairs only.

In Tables 4 and 5 we reestimate equations (3), substituting the variables CHINPOP $*(1-S E A S I A 2)$ and CHINPOP $*$ SEASIA2 for CHINPOP, where SEASIA2 is a dummy variable that equals one when both trading partners are in Southeast Asia and zero otherwise. We see immediately that the coefficients on CHINPOP $*$ SEASIA2 in Tables 4 and 5 are essentially the same (though slightly smaller in all cases) as the coefficients on CHINPOP in Tables 2 and 3, respectively, and that the marginal effect of CHINPOP for Southeast Asian country pairs is less than two (five) percent of that for other country pairs in all cases in 1980 (1990). This difference in the impact on bilateral trade of a marginal increase in the probability that, if we select an individual at random from each country, both will be ethnic Chinese is far outweighed, however, by the difference in the average probability levels between Southeast Asian country pairs and other country pairs. Table 6 shows the percentage increase in bilateral trade that can be attributed to ethnic Chinese networks, evaluated at the average levels of CHINPOP for Southeast Asian country pairs and all other country pairs. ${ }^{11}$ The economic impact of ethnic Chinese networks within Southeast Asia is 28-48 times greater in 1980 and 22-55 times greater in 1990, not counting in the second range the conservatively aggregated organized

\footnotetext{
${ }^{11}$ The figures in Table 6 were computed as if $a_{k}=0$ in equations (2). For $a_{k}>0$, the presence of ethnic Chinese networks could mean the difference between zero bilateral trade and positive bilateral trade for some country pairs, making the percentage increase in trade attributable to ethnic Chinese networks infinite. Using the estimated values of $a_{k}$ and the mean values of $V_{i j k}$ to compute the percentage increases in bilateral trade attributable to ethnic Chinese networks would yield estimates that are higher than those assuming $a_{k}=0$, but not sufficiently higher to change the figures reported in Table 6 because $a_{k}$ is small relative to the mean values of $V_{i j k}$.
} 
exchange commodity group, for which $C H I N P O P * S E A S I A 2$ is not statistically significant in 1990.

Turning to our main hypothesis, we see from Table 6 that within Southeast Asia the impact of ethnic Chinese networks on bilateral trade is substantially greater for differentiated products than for either homogeneous product group in 1980 and especially in 1990. This result holds for both the conservative and liberal aggregations. The same cannot be said for other country pairs, however, and indeed for the conservative aggregation in 1990 the economic impacts of ethnic Chinese networks are virtually indistinguishable across commodity groups. We can also make an approximate assessment of the statistical significance of the differences across commodity groups between the coefficients reported in Tables 4 and 5 by estimating four SUR systems (one for each year and aggregation), where the dependent variables are $\ln (1+$ $\left.V_{i j k}\right),{ }^{12}$ and testing for equality of coefficients across equations. Of course the change in estimation procedure changes the coefficients on the CHINPOP variables, but the differences across commodity groups remain relatively constant as all coefficients increase $10-20$ percent, with the inflation of the coefficients for the differentiated commodity groups always in the low end of that range. The standard errors for the CHINPOP coefficients unfortunately increase by 30 to over 100 percent, though all coefficients that were significant in Tables 4 and 5 remain so. As expected, for $C H I N P O P *(1-S E A S I A 2)$ we cannot reject the hypothesis of equality of coefficients for the differentiated commodity group and either homogeneous commodity group for any year in any aggregation. For $C H I N P O P * S E A S I A 2$ we cannot reject the hypothesis of

\footnotetext{
${ }^{12}$ In other words, we work with the log transform of equations (1) instead of equations (2), and add one to the dependent variables so that all zero observations can be retained.
} 
equality of coefficients for the differentiated commodity group and either homogeneous commodity group in 1980 at any conventional level of significance, though rejection is close for the organized exchange group, with significance levels of 17 and 12 percent for the conservative and liberal aggregations, respectively. For 1990, however, we can reject the hypothesis of equality of coefficients between the differentiated and both homogeneous commodity groups at the ten percent level for the conservative aggregation and at the five percent level for the liberal aggregation. ${ }^{13}$

In the same way we can assess the statistical significance of the differences across commodity groups of the coefficients on COLOTIE, though for 1990 the change in estimation procedure inflates the coefficients for the reference priced commodity groups considerably relative to the other commodity groups. For both years we can reject the hypothesis of equality of coefficients between the differentiated and the organized exchange commodity groups at the one percent level for both aggregations, and we can reject the hypothesis of equality of coefficients between the differentiated and the reference priced commodity groups at the ten (five) percent level for the conservative (liberal) aggregation in 1980 and at the one percent level for both aggregations in $1990 .{ }^{14}$

To summarize, distinguishing between Southeast Asian country pairs and other country pairs, as we do in Tables 4-5, yields results that are less supportive than those reported in Tables

\footnotetext{
${ }^{13}$ For both $C H I N P O P *(1-S E A S I A 2)$ and $C H I N P O P * S E A S I A 2$ we cannot reject the hypothesis of equality of coefficients between the reference priced and organized exchange commodity groups for any year for either aggregation.

${ }^{14} \mathrm{We}$ cannot reject the hypothesis of equality of coefficients on COLOTIE between the reference priced and the organized exchange commodity groups for any year or aggregation except the conservative aggregation in 1980 , for which we can reject equality at the ten percent level.
} 
2-3 of our hypothesis regarding the mechanism through which ethnic Chinese networks overcome informal barriers to international trade. While the economic impact of ethnic Chinese networks on bilateral trade in differentiated products is much greater than their impact on bilateral trade in homogeneous products (especially those traded on organized exchanges) within Southeast Asia, this is not true for other country pairs. Combining this finding with the result that the marginal impact of ethnic Chinese networks is much lower within Southeast Asia suggests the following interpretation. Ethnic Chinese communities that are small fractions of their countries' populations are close-knit and therefore both share information very thoroughly and are able to effectively implement community sanctions that deter opportunistic behavior. They help facilitate international trade mainly by supplementing a weak international legal system, with at best a secondary effect through provision of market information and matching and referral services. ${ }^{15}$ Ethnic Chinese communities that are large fractions of their countries' populations and between which direct connections across international borders are more numerous share information less thoroughly, accounting for their lower marginal impact, but occupy a much more diverse range of business niches and are better able to match international buyers and sellers in characteristics space, accounting for their greater impact on bilateral trade in differentiated than in homogeneous products. Indeed, within Southeast Asia ethnic Chinese networks affect bilateral trade very much like past colonial relationships, which presumably provide little added basis for community enforcement of sanctions.

\footnotetext{
${ }^{15}$ This interpretation is based only loosely on the evidence provided by the coefficients on CHINPOP for other country pairs in that some of these country pairs include one Southeast Asian country. In Table 7 below we examine the effects on the coefficients on CHINPOP of taking out country pairs that include China.
} 
Overall, the 1990 results support our interpretation more clearly than the 1980 results because, within Southeast Asia, the differences in the impacts of ethnic Chinese networks across commodity groups are statistically as well as economically significant. Though with only two years of data a decade apart our study is not well suited to analysis of time trends, it is nevertheless interesting to note from Table 6 that the impact of ethnic Chinese networks on bilateral trade is lower in 1990 than in 1980 for every commodity group in both aggregations. The same is true for past colonial relationships, as we can see by comparing Tables 4 and 5 . This could reflect improvements in communications technology and strengthening of international legal institutions, or it could reflect weakening of ethnic bonds and colonial ties.

We conclude this section with checks for robustness of our results to some changes in sample and specification. At the beginning of this section we noted that, from the Frankel (1997) sample of 63 countries, we omitted six countries in 1980 and five countries in 1990 due to lack of ethnic Chinese population data. Given the identities of the omitted countries (Algeria, Iceland, Israel, Tunisia, and Yugoslavia in both years plus Kuwait in 1980), it seems not far wrong to assume their ethnic Chinese populations are zero and include them in the sample. This results in no qualitative changes in any of the coefficients of interest (i.e., those on the CHINPOP variables, COLOTIE, and LANGUAGE) for any year or aggregation. We also noted at the beginning of this section a concern that China-Hong Kong and Hong Kong-Taiwan trade might be artificially inflated by inclusion of China-Taiwan trade. These two country pairs could conceivably account for why we find the economic impact of ethnic Chinese networks within Southeast Asia to be so large. We therefore examined the results of omitting not only ChinaTaiwan trade but also China-Hong Kong and Hong Kong-Taiwan trade. The effect was actually 
to raise the marginal impacts of ethnic Chinese networks within Southeast Asia, ${ }^{16}$ which was not surprising given that the ethnic Chinese population shares exceed 90 percent in each of the three countries involved. In combination with the reduced mean values of $C H I N P O P * S E A S I A 2$ this left the economic impacts of ethnic Chinese networks virtually unchanged or increased from their values in Table 6 in all cases.

A final concern we will address is that what we are calling an ethnic Chinese network effect is really only an emigrant effect rather than the effect of a set of multilaterally linked national networks. In other words, it could be that our results are driven entirely by the connections that emigrants established between China and their destination countries, just as immigrants connected the United States to their source countries in the study by Gould (1994) (although the immigrants in his study were much more recent than the typical emigrant from China). To check this possibility we created a dummy variable, CHINA, that takes on the value one if a country pair includes China and zero otherwise, and reestimated equations (3), substituting the variables $C H I N P O P *(1-S E A S I A 2) *(1-C H I N A)$, CHINPOP $* S E A S I A 2 *(1-C H I N A)$, and CHINPOP $*$ CHINA for CHINPOP. The results are reported in Table $7 .{ }^{17}$ We see that the marginal impact of ethnic Chinese networks increases compared to Tables 4 and 5 in all cases except for the organized exchange commodity groups within Southeast Asia in 1990. The percentage increases in bilateral trade attributable to ethnic Chinese networks within Southeast Asia fall slightly (substantially for the organized exchange

\footnotetext{
${ }^{16}$ All other coefficients were essentially unchanged.

${ }^{17}$ To save space we do not report coefficients on other variables, which were essentially unchanged.
} 
commodity groups in 1990) compared to their values in Table 6, while these percentage increases for other country pairs are essentially unchanged. ${ }^{18}$

The results in Table 7 also provide an additional check on the possibility that the product of ethnic Chinese population shares is associated with a greater increase in bilateral trade in differentiated than in homogeneous products (at least within Southeast Asia) because it is proxying for taste similarity. We might expect such taste similarity to be reflected most strongly in trade of "cultural" goods with China, e.g., import of Chinese herbal medicines by ethnic Chinese abroad. In this case removing country pairs that include China from the estimation of the coefficients on the product of ethnic Chinese population shares should narrow the differences in the coefficients between the differentiated and homogeneous commodity groups. A comparison of Table 7 with Tables 4 and 5 shows that if anything the opposite is true within Southeast Asia, though for other country pairs we do observe that the coefficient on the organized exchange commodity group now exceeds that for the differentiated commodity group for the conservative aggregation in 1990 .

\section{Conclusions}

Our study confirms what other studies had suggested: informal barriers to trade are quantitatively important. For differentiated products within Southeast Asia, the smallest of our

\footnotetext{
${ }^{18}$ The economic impacts of $C H I N P O P * C H I N A$ are 3-4 times greater than for $C H I N P O P *(1-S E A S I A 2) *(1-C H I N A)$ in 1980 and 3-6 times greater in 1990. All economic impacts were computed as in Table 6 using the mean values of CHINPOP $*(1-S E A S I A 2) *(1-C H I N A), C H I N P O P * S E A S I A 2 *(1-C H I N A)$, and $C H I N P O P * C H I N A$ for 1980 and 1990 . These are, respectively, 0.000130 and $0.000215 ; 0.175$ and 0.164 ; and 0.0373 and 0.0359 .
} 
estimates (for the conservative aggregation in 1990) is that ethnic Chinese networks increase bilateral trade by over 150 percent. Regarding the mechanism through which business and social networks overcome informal barriers to trade, our study comes down squarely on both sides: the effects of ethnic Chinese networks within Southeast Asia suggest that providing market information and matching and referral services is key, while their effects for other country pairs suggest that what matters is community enforcement of sanctions that deter opportunistic behavior. Our results thus point to two areas of concern for policy makers: inadequate information regarding trading opportunities, and a weak international legal system.

In the latter regard, although institutions such as letters of credit and international commercial arbitration are private, their authority ultimately relies on enforcement by national court systems. International commercial arbitration in particular could benefit from harmonization of national legal treatments of the international arbitral process. ${ }^{19}$ Regarding information, it is common for governments to sponsor trade missions and to run international trade promotion organizations (see Rauch 1996 and the references therein). Yet, as Rhee and Soulier (1989, p. 25) point out, such efforts complement rather than substitute for the services of private intermediaries because the latter provide greater "depth of information". Private intermediaries are typically small and specialized, but our study suggests that ethnic Chinese networks facilitated international trade primarily through provision of market information and matching and referral services only within Southeast Asia, where ethnic Chinese communities are relatively large fractions of their countries' populations and have relatively numerous direct

\footnotetext{
${ }^{19}$ For thoughts on how national courts could accelerate the international arbitral process, see Gaudet (1998).
} 
connections across international borders. Indeed, some governments have come to the conclusion that large-scale private intermediaries are what is needed: the governments of Korea and Turkey subsidized (in the 1970s and 1980s, respectively) the formation of general trading companies in imitation of the Japanese sogo shosha (Rauch 1996). We must keep in mind, however, that the costs of establishing ethnic Chinese networks have been sunk, whereas the costs of establishing new general trading companies have not. 


\section{References}

Boisso, Dale, and Michael Ferrantino. 1997. "Economic Distance, Cultural Distance, and Openness in International Trade: Empirical Puzzles." Journal of Economic Integration 12(4): 456-484.

Craig, W. Laurence, William W. Park, and Jan Paulsson. 1985. International Chamber of Commerce Arbitration (New York: Oceana Publications).

Deardorff, Alan V. 1998. "Determinants of Bilateral Trade: Does Gravity Work in a Neoclassical World?" In Jeffrey A. Frankel, ed., The Regionalization of the World Economy (Chicago: University of Chicago): 7-28.

del Busto, Charles. 1994. ICC Guide to Documentary Credit Operations for the UCP 500 (Paris: ICC Publishing).

Eaton, Jonathan, and Akiko Tamura. 1994. "Bilateralism and Regionalism in Japanese and U.S. Trade and Direct Foreign Investment Patterns." Journal of the Japanese and International Economies 8: 478-510.

Encyclopedia Britannica. 1997. Internet Edition.

Feenstra, Robert C., Robert E. Lipsey, and Harry P. Bowen. 1997. "World Trade Flows, 19701992, With Production and Tariff Data." National Bureau of Economic Research Working Paper No. 5910.

Frankel, Jeffrey A. 1997. Regional Trading Blocs in the World Economic System (Washington, D. C: Institute for International Economics).

Freedman, Maurice. 1967. "Immigrants and Associations: Chinese in Nineteenth-Century Singapore." In L. A. Fallers, ed., Immigrants and Associations (The Hague: Mouton): $17-48$.

Gaudet, Michel (Liber Amicorum to). 1998. Improving International Arbitration (Paris: ICC Publishing).

Gould, David M. 1994. "Immigrant Links to the Home Country: Empirical Implications for U.S. Bilateral Trade Flows." Review of Economics and Statistics 76: 302-316.

Greif, Avner. 1989. "Reputation and Coalitions in Medieval Trade: Evidence on the Maghribi Traders." Journal of Economic History 49(4): 857-882. 
Greif, Avner. 1993. "Contract Enforceability and Economic Institutions in Early Trade: The Maghribi Traders' Coalition.” American Economic Review 83(3): 525-548.

Grimes, Barbara F., ed. 1992. Ethnologue Index, 12 th Edition (Dallas, TX: Summer Institute of Linguistics).

Head, Keith, and John Ries. 1999. "Overseas Investment and Firm Exports." Review of International Economics, forthcoming.

Helliwell, John F. 1998. How Much Do National Borders Matter? (Washington, D. C.: Brookings Institution).

Helpman, Elhanan. 1987. "Imperfect Competition and International Trade: Evidence from Fourteen Industrial Countries." Journal of the Japanese and International Economies 1: $62-81$.

Kotkin, Joel. 1992. Tribes: How Race, Religion, and Identity Determine Success in the New Global Economy (New York: Random House).

Leong, Weng Kam. 1999. "Singapore Chinese Chamber of Commerce and Industry is First Secretariat for World Meeting." The Straits Times March 15: 36.

Lever-Tracy, Constance, David Ip, and Noel Tracy. 1996. The Chinese Diaspora and Mainland China (New York: St. Martin's Press).

Linder, Staffan Burenstam. 1961. An Essay on Trade and Transformation (Uppsala: Almqvist and Wiksells).

McCallum, John. 1995. "National Borders Matter: Canada-U. S. Regional Trade Patterns." American Economic Review 85: 615-623.

McKendrick, David (Research Director for UCSD Data Storage Project). Personal communication, February 1998.

Overseas Chinese Affairs Commission. 1991. Overseas Chinese Economy Yearbook, 1990 (Taipei).

Poston, Dudley L. and Mei-Yu Yu. 1990. "The Distribution of Overseas Chinese in the Contemporary World." International Migration Review 24: 480-508.

Rauch, James E. 1996. "Trade and Search: Social Capital, Sogo Shosha, and Spillovers." National Bureau of Economic Research Working Paper No. 5618. 
Rauch, James E. and Casella, Alessandra. 1998. "Overcoming Informational Barriers to International Resource Allocation: Prices and Group Ties." National Bureau of Economic Research Working Paper No. 6628.

Rauch, James E. 1999. "Networks Versus Markets in International Trade." Journal of International Economics 48(1): 7-35.

Redding, Gordon. 1995. "Overseas Chinese Networks: Understanding the Enigma." Long Range Planning 28: 61-69.

Rhee, Yung Whee and Soulier, Christine. 1989. "Small Trading Companies and a Successful Export Response: Lessons from Hong Kong." World Bank Industry and Energy Department Working Paper, Industry Series Paper No. 16.

Trefler, Daniel. 1995. "The Case of the Missing Trade and Other Mysteries." American Economic Review 85(5): 1029-1046.

Wei, Shang-Jin. 1996. "Intra-National Versus International Trade: How Stubborn are Nations in Global Integration?" National Bureau of Economic Research Working Paper No. 5531 .

Weidenbaum, Murray, and Samuel Hughes. 1996. The Bamboo Network (New York: The Free Press). 
</ref_section> 
Table 1

Countries, Chinese Population (CHIN), and Population (POP, millions), 1980 and 1990

\begin{tabular}{|c|c|c|c|c|}
\hline Country & CHIN (1980) & POP (1980) & CHIN (1990) & POP (1990) \\
\hline Canada & 289245 & 23.9 & 550000 & 26.52 \\
\hline France & 210000 & 53.5 & 150000 & 56.44 \\
\hline W. Germany & 20000 & 60.9 & 40000 & 63.23 \\
\hline Italy & 3500 & 56.9 & 6000 & 57.66 \\
\hline Japan & 54607 & 116.8 & 137499 & 123.54 \\
\hline UK & 230000 & 55.9 & 230000 & 57.41 \\
\hline US & 806040 & 227.7 & 1800000 & 249.97 \\
\hline Austria & 4500 & 7.5 & 3800 & 7.71 \\
\hline Belgium & 4000 & 9.8 & 11000 & 9.84 \\
\hline Denmark & 2000 & 5.1 & 5000 & 5.14 \\
\hline Finland & 9 & 4.9 & 9 & 4.99 \\
\hline Netherlands & 60000 & 14.1 & 70000 & 14.94 \\
\hline Norway & 600 & 4.1 & 950 & 4.24 \\
\hline Sweden & 5000 & 8.3 & 9000 & 8.56 \\
\hline Switzerland & 3200 & 6.5 & 7500 & 6.71 \\
\hline Australia & 122700 & 14.5 & 330300 & 17.09 \\
\hline Greece & 186 & 9.6 & 120 & 10.12 \\
\hline Iceland & & 0.23 & & \\
\hline Ireland & 1000 & 3.3 & 1000 & 3.5 \\
\hline New Zealand & 19248 & 3.3 & 30000 & 3.35 \\
\hline Portugal & 2500 & 9.8 & 4700 & 10.53 \\
\hline Spain & 3500 & 37.4 & 15000 & 38.96 \\
\hline S. Africa & 11000 & 29.3 & 20000 & 35.28 \\
\hline Turkey & 36000 & 44.9 & 60000 & 58.69 \\
\hline Yugoslavia & & 22.3 & & \\
\hline Israel & & 3.9 & & \\
\hline Argentina & 2000 & 27.7 & 12000 & 32.32 \\
\hline Brazil & 11213 & 118.7 & 100000 & 150.37 \\
\hline Chile & 2000 & 11.1 & 13000 & 13.17 \\
\hline Colombia & 5600 & 26.7 & 4000 & 32.99 \\
\hline Ecuador & 12800 & 8 & 16000 & 10.78 \\
\hline Mexico & 20000 & 69.8 & 20000 & 86.15 \\
\hline Peru & 52000 & 17.4 & 500000 & 22.33 \\
\hline Venezuela & 14000 & 14.9 & 14000 & 19.73 \\
\hline Bolivia & 2000 & 5.6 & 4000 & 7.4 \\
\hline Paraguay & 4000 & 3.2 & 6000 & 4.28 \\
\hline Uruguay & 250 & 2.9 & 350 & 3.09 \\
\hline Algeria & & 18.9 & & \\
\hline Libya & 300 & 3 & 356 & 4.54 \\
\hline Nigeria & 1000 & 84.7 & 1500 & 117.5 \\
\hline Egypt & 20 & 39.8 & 110 & 53.15 \\
\hline
\end{tabular}


Table 1 (continued)

\section{Countries, Chinese Population (CHIN), and Population (POP, millions),} 1980 and 1990

\begin{tabular}{lrrrc} 
Country & CHIN (1980) & POP (1980) & CHIN (1990) & POP (1990) \\
\hline Morocco & 10 & 20.2 & 20 & 25.06 \\
Tunisia & & 6.4 & & \\
Sudan & 45 & 18.7 & 45 & 25.2 \\
Ghana & 300 & 11.7 & 320 & 15.03 \\
Kenya & 100 & 15.9 & 150 & 24.03 \\
Ethiopia & 50 & 31.1 & 55 & 50.97 \\
Iran & 300 & 38.4 & 300 & 54.61 \\
Kuwait & & 1.4 & 200 & 2.14 \\
Saudi Arabia & 45000 & 9 & 30000 & 14.87 \\
Indonesia & 6150000 & 146.6 & 7260000 & 179.3 \\
Taiwan & 17444000 & 17.8 & 19943000 & 20.35 \\
Hong Kong & 4947000 & 5.1 & 5626000 & 5.8 \\
India & 110000 & 673.2 & 21000 & 827.05 \\
S.Korea & 46192 & 38.2 & 23328 & 42.79 \\
Malaysia & 3630542 & 13.9 & 5202000 & 17.86 \\
Pakistan & 3600 & 82.2 & 3600 & 112.05 \\
Philippines & 1036000 & 49 & 800000 & 61.48 \\
Singapore & 1856237 & 2.4 & 2038000 & 3 \\
Thailand & 4800000 & 47 & 4800000 & 57.2 \\
Hungary & 24 & 10.8 & 24 & 10.55 \\
Poland & 77 & 35.8 & 77 & 38.18 \\
China & 976.7 & 1032608000 & 1122.4
\end{tabular}

Sources: Poston and Yu (1990), Overseas Chinese Economy Year Book 1990 (1991). 
Table 2

Dependent Variable: Log of 1980 Bilateral Trade in Organized Exchange, Reference Priced, and Differentiated Commodities

\begin{tabular}{|c|c|c|c|c|c|c|}
\hline \multirow[b]{2}{*}{ Variable } & \multicolumn{3}{|c|}{ Conservative aggregation } & \multicolumn{3}{|c|}{ Liberal aggregation } \\
\hline & Org. & Ref. & Dif. & Org. & Ref. & Dif. \\
\hline Intercept & $\begin{array}{l}-44.559 \\
(3.903)\end{array}$ & $\begin{array}{r}-21.585 \\
(2.861)\end{array}$ & $\begin{array}{r}-16.755 \\
(2.638)\end{array}$ & $\begin{array}{r}-36.179 \\
(3.444)\end{array}$ & $\begin{array}{r}-23.941 \\
(2.750)\end{array}$ & $\begin{array}{r}-16.493 \\
(2.680)\end{array}$ \\
\hline $\begin{array}{l}\text { Threshold } \\
\text { (\$US Thous.) }\end{array}$ & $\begin{array}{l}140.345^{\mathrm{a}} \\
(18.900)\end{array}$ & $\begin{array}{l}117.701^{\mathrm{a}} \\
(14.975)\end{array}$ & $\begin{array}{r}94.659^{a} \\
(16.615)\end{array}$ & $\begin{array}{l}147.848^{a} \\
(20.338)\end{array}$ & $\begin{array}{l}120.655^{\mathrm{a}} \\
(15.459)\end{array}$ & $\begin{array}{r}86.274^{\mathrm{a}} \\
(14.250)\end{array}$ \\
\hline $\begin{array}{l}\ln \left(G N P_{i} G N P_{j}\right) \\
(1980)\end{array}$ & $\begin{array}{r}1.077^{\mathrm{a}} \\
(0.041)\end{array}$ & $\begin{array}{r}0.911^{\mathrm{a}} \\
(0.028)\end{array}$ & $\begin{array}{r}0.903^{\mathrm{a}} \\
(0.027)\end{array}$ & $\begin{array}{r}0.999^{\mathrm{a}} \\
(0.037)\end{array}$ & $\begin{array}{c}0.959^{\mathrm{a}} \\
(0.027)\end{array}$ & $\begin{array}{r}0.898^{\mathrm{a}} \\
(0.028)\end{array}$ \\
\hline $\begin{array}{l}\ln \left(P G N P_{i} P G N P_{j}\right. \\
)(1980)\end{array}$ & $\begin{array}{r}0.382^{\mathrm{a}} \\
(0.051)\end{array}$ & $\begin{array}{r}0.494^{\mathrm{a}} \\
(0.036)\end{array}$ & $\begin{array}{r}0.535^{a} \\
(0.036)\end{array}$ & $\begin{array}{r}0.392^{a} \\
(0.046)\end{array}$ & $\begin{array}{r}0.499^{\mathrm{a}} \\
(0.036)\end{array}$ & $\begin{array}{r}0.547^{\mathrm{a}} \\
(0.036)\end{array}$ \\
\hline $\ln (D I S T A N C E)$ & $\begin{array}{l}-1.419^{a} \\
(0.111)\end{array}$ & $\begin{array}{l}-1.118^{a} \\
(0.086)\end{array}$ & $\begin{array}{l}-0.861^{a} \\
(0.082)\end{array}$ & $\begin{array}{l}-1.271^{\mathrm{a}} \\
(0.102)\end{array}$ & $\begin{array}{l}-1.198^{a} \\
(0.083)\end{array}$ & $\begin{array}{l}-0.830^{\mathrm{a}} \\
(0.083)\end{array}$ \\
\hline $\ln (R E M O T E)$ & $\begin{array}{r}2.009^{\mathrm{a}} \\
(0.222)\end{array}$ & $\begin{array}{r}0.699^{a} \\
(0.172)\end{array}$ & $\begin{array}{r}0.323^{\mathrm{b}} \\
(0.159)\end{array}$ & $\begin{array}{r}1.586^{\mathrm{a}} \\
(0.198)\end{array}$ & $\begin{array}{r}0.797^{\mathrm{a}} \\
(0.164)\end{array}$ & $\begin{array}{r}0.284^{\mathrm{c}} \\
(0.161)\end{array}$ \\
\hline$A D J A C E N T$ & $\begin{array}{c}0.046 \\
(0.353)\end{array}$ & $\begin{array}{r}0.515^{\mathrm{c}} \\
(0.272)\end{array}$ & $\begin{array}{r}0.643^{\mathrm{b}} \\
(0.275)\end{array}$ & $\begin{array}{c}0.123 \\
(0.323)\end{array}$ & $\begin{array}{c}0.370 \\
(0.287)\end{array}$ & $\begin{array}{r}0.700^{\mathrm{b}} \\
(0.279)\end{array}$ \\
\hline$E E C$ & $\begin{array}{l}-0.353 \\
(0.228)\end{array}$ & $\begin{array}{l}-0.063 \\
(0.160)\end{array}$ & $\begin{array}{l}-0.023 \\
(0.148)\end{array}$ & $\begin{array}{l}-0.483^{b} \\
(0.206)\end{array}$ & $\begin{array}{l}-0.102 \\
(0.162)\end{array}$ & $\begin{array}{c}0.017 \\
(0.150)\end{array}$ \\
\hline EFTA & $\begin{array}{l}-0.643 \\
(0.410)\end{array}$ & $\begin{array}{c}0.230 \\
(0.219)\end{array}$ & $\begin{array}{c}0.432^{b} \\
(0.219)\end{array}$ & $\begin{array}{c}0.437 \\
(0.306)\end{array}$ & $\begin{array}{c}0.299 \\
(0.210)\end{array}$ & $\begin{array}{c}0.453^{b} \\
(0.224)\end{array}$ \\
\hline$L A N G U A G E$ & $\begin{array}{c}0.092 \\
(0.471)\end{array}$ & $\begin{array}{c}0.049 \\
(0.369)\end{array}$ & $\begin{array}{l}-0.383 \\
(0.276)\end{array}$ & $\begin{array}{c}0.062 \\
(0.440)\end{array}$ & $\begin{array}{l}-0.022 \\
(0.362)\end{array}$ & $\begin{array}{l}-0.335 \\
(0.279)\end{array}$ \\
\hline COLOTIE & $\begin{array}{c}0.631^{\mathrm{a}} \\
(0.234)\end{array}$ & $\begin{array}{r}0.932^{\mathrm{a}} \\
(0.175)\end{array}$ & $\begin{array}{c}1.260^{\mathrm{a}} \\
(0.166)\end{array}$ & $\begin{array}{r}0.658^{\mathrm{a}} \\
(0.211)\end{array}$ & $\begin{array}{c}0.910^{\mathrm{a}} \\
(0.176)\end{array}$ & $\begin{array}{r}1.269^{\mathrm{a}} \\
(0.167)\end{array}$ \\
\hline CHINPOP & $\begin{array}{r}3.719^{\mathrm{a}} \\
(1.063)\end{array}$ & $\begin{array}{c}4.798^{\mathrm{a}} \\
(0.865)\end{array}$ & $\begin{array}{c}6.024^{\mathrm{a}} \\
(0.918)\end{array}$ & $\begin{array}{r}3.724^{\mathrm{a}} \\
(1.035)\end{array}$ & $\begin{array}{c}4.857^{\mathrm{a}} \\
(0.818)\end{array}$ & $\begin{array}{r}6.102^{a} \\
(0.928)\end{array}$ \\
\hline Log Likelihood & -16262.4 & -16777.5 & -18432.3 & -17238.3 & -16368.7 & -18328.6 \\
\hline
\end{tabular}

Maximum likelihood estimation of threshold Tobit model.

Eicker-White standard errors in parentheses. Number of observations $=1595$.

${ }^{\mathrm{a}}$ Significant at one percent level. ${ }^{\mathrm{b}}$ Significant at five percent level. ${ }^{\mathrm{c}}$ Significant at ten percent level. 
Table 3

Dependent Variable: Log of 1990 Bilateral Trade in Organized Exchange, Reference Priced, and Differentiated Commodities

Conservative aggregation

Liberal aggregation

\begin{tabular}{|c|c|c|c|c|c|c|}
\hline Variable & Org. & Ref. & Dif. & Org. & Ref. & Dif. \\
\hline Intercept & $\begin{array}{r}-45.242 \\
(3.596)\end{array}$ & $\begin{array}{r}-26.565 \\
(2.610)\end{array}$ & $\begin{array}{r}-19.761 \\
(2.520)\end{array}$ & $\begin{array}{c}-38.351 \\
(3.260)\end{array}$ & $\begin{array}{r}-27.337 \\
(2.567)\end{array}$ & $\begin{array}{r}-19.491 \\
(2.546)\end{array}$ \\
\hline $\begin{array}{l}\text { Threshold } \\
\text { (\$US Thous.) }\end{array}$ & $\begin{array}{l}106.728^{a} \\
(14.301)\end{array}$ & $\begin{array}{l}136.924^{\mathrm{a}} \\
(19.859)\end{array}$ & $\begin{array}{l}123.207^{\mathrm{a}} \\
(21.687)\end{array}$ & $\begin{array}{l}130.793^{\mathrm{a}} \\
(17.358)\end{array}$ & $\begin{array}{l}120.529^{a} \\
(17.729)\end{array}$ & $\begin{array}{l}115.661^{\mathrm{a}} \\
(19.774)\end{array}$ \\
\hline $\begin{array}{l}\ln \left(G N P_{i} G N P_{j}\right) \\
(1990)\end{array}$ & $\begin{array}{r}1.039^{a} \\
(0.036)\end{array}$ & $\begin{array}{r}0.965^{\mathrm{a}} \\
(0.024)\end{array}$ & $\begin{array}{r}0.979^{\mathrm{a}} \\
(0.024)\end{array}$ & $\begin{array}{r}0.987^{\mathrm{a}} \\
(0.032)\end{array}$ & $\begin{array}{r}0.982^{\mathrm{a}} \\
(0.024)\end{array}$ & $\begin{array}{r}0.986^{\mathrm{a}} \\
(0.024)\end{array}$ \\
\hline $\begin{array}{l}\ln \left(P G N P_{i} P G N P_{j}\right. \\
)(1990)\end{array}$ & $\begin{array}{r}0.158^{a} \\
(0.040)\end{array}$ & $\begin{array}{r}0.224^{\mathrm{a}} \\
(0.026)\end{array}$ & $\begin{array}{r}0.276^{\mathrm{a}} \\
(0.026)\end{array}$ & $\begin{array}{r}0.174^{\mathrm{a}} \\
(0.036)\end{array}$ & $\begin{array}{r}0.216^{\mathrm{a}} \\
(0.026)\end{array}$ & $\begin{array}{r}0.288^{\mathrm{a}} \\
(0.026)\end{array}$ \\
\hline $\ln (D I S T A N C E)$ & $\begin{array}{l}-1.322^{a} \\
(0.106)\end{array}$ & $\begin{array}{l}-0.930^{\mathrm{a}} \\
(0.083)\end{array}$ & $\begin{array}{l}-0.768^{a} \\
(0.084)\end{array}$ & $\begin{array}{l}-1.172^{a} \\
(0.099)\end{array}$ & $\begin{array}{l}-0.990^{a} \\
(0.083)\end{array}$ & $\begin{array}{l}-0.771^{\mathrm{a}} \\
(0.085)\end{array}$ \\
\hline $\ln (R E M O T E)$ & $\begin{array}{c}2.197^{\mathrm{a}} \\
(0.207)\end{array}$ & $\begin{array}{r}1.040^{\mathrm{a}} \\
(0.156)\end{array}$ & $\begin{array}{r}0.558^{a} \\
(0.153)\end{array}$ & $\begin{array}{l}1.820^{\mathrm{a}} \\
(0.190)\end{array}$ & $\begin{array}{r}1.093^{\mathrm{a}} \\
(0.153)\end{array}$ & $\begin{array}{r}0.519^{\mathrm{a}} \\
(0.155)\end{array}$ \\
\hline$A D J A C E N T$ & $\begin{array}{r}0.613^{c} \\
(0.339)\end{array}$ & $\begin{array}{r}0.856^{\mathrm{a}} \\
(0.272)\end{array}$ & $\begin{array}{r}0.926^{\mathrm{a}} \\
(0.275)\end{array}$ & $\begin{array}{c}0.660^{\mathrm{b}} \\
(0.314)\end{array}$ & $\begin{array}{r}0.750^{\mathrm{a}} \\
(0.274)\end{array}$ & $\begin{array}{r}0.969^{\mathrm{a}} \\
(0.280)\end{array}$ \\
\hline$E E C$ & $\begin{array}{l}-0.043 \\
(0.225)\end{array}$ & $\begin{array}{c}0.279 \\
(0.172)\end{array}$ & $\begin{array}{c}0.269 \\
(0.166)\end{array}$ & $\begin{array}{l}-0.048 \\
(0.211)\end{array}$ & $\begin{array}{c}0.214 \\
(0.171)\end{array}$ & $\begin{array}{c}0.267 \\
(0.168)\end{array}$ \\
\hline EFTA & $\begin{array}{l}-0.366 \\
(0.443)\end{array}$ & $\begin{array}{c}0.244 \\
(0.205)\end{array}$ & $\begin{array}{c}0.368 \\
(0.233)\end{array}$ & $\begin{array}{c}0.014 \\
(0.321)\end{array}$ & $\begin{array}{c}0.249 \\
(0.193)\end{array}$ & $\begin{array}{c}0.367 \\
(0.240)\end{array}$ \\
\hline$L A N G U A G E$ & $\begin{array}{r}0.912^{\mathrm{b}} \\
(0.441)\end{array}$ & $\begin{array}{c}1.253^{\mathrm{a}} \\
(0.338)\end{array}$ & $\begin{array}{c}0.332 \\
(0.319)\end{array}$ & $\begin{array}{c}0.741^{\mathrm{c}} \\
(0.415)\end{array}$ & $\begin{array}{c}1.406^{\mathrm{a}} \\
(0.340)\end{array}$ & $\begin{array}{c}0.300 \\
(0.318)\end{array}$ \\
\hline COLOTIE & $\begin{array}{c}0.342 \\
(0.213)\end{array}$ & $\begin{array}{r}0.432^{\mathrm{a}} \\
(0.153)\end{array}$ & $\begin{array}{r}1.002^{\mathrm{a}} \\
(0.153)\end{array}$ & $\begin{array}{c}0.451^{\mathrm{b}} \\
(0.193)\end{array}$ & $\begin{array}{c}0.352^{\mathrm{b}} \\
(0.154)\end{array}$ & $\begin{array}{r}1.032^{\mathrm{a}} \\
(0.156)\end{array}$ \\
\hline CHINPOP & $\begin{array}{c}1.965 \\
(1.354)\end{array}$ & $\begin{array}{r}3.063^{\mathrm{a}} \\
(0.722)\end{array}$ & $\begin{array}{c}4.893^{\mathrm{a}} \\
(0.905)\end{array}$ & $\begin{array}{c}2.211^{\mathrm{c}} \\
(1.263)\end{array}$ & $\begin{array}{c}2.912^{\mathrm{a}} \\
(0.701)\end{array}$ & $\begin{array}{c}5.051^{\mathrm{a}} \\
(0.928)\end{array}$ \\
\hline Log Likelihood & -17286.9 & -18455.6 & -20073.9 & -18186.8 & -18333.9 & -19873.2 \\
\hline
\end{tabular}

Maximum likelihood estimation of threshold Tobit model.

Eicker-White standard errors in parentheses. Number of observations $=1652$.

${ }^{a}$ Significant at one percent level. ${ }^{b}$ Significant at five percent level. 'Significant at ten percent level. 
Table 4

Dependent Variable: Log of 1980 Bilateral Trade in Organized Exchange, Reference Priced, and Differentiated Commodities

Conservative aggregation

Liberal aggregation

\begin{tabular}{|c|c|c|c|c|c|c|}
\hline Variable & Org. & Ref. & Dif. & Org. & Ref. & Dif. \\
\hline Intercept & $\begin{array}{c}-42.859 \\
(3.876)\end{array}$ & $\begin{array}{l}-19.842 \\
(2.841)\end{array}$ & $\begin{array}{r}-14.652 \\
(2.629)\end{array}$ & $\begin{array}{r}-34.578 \\
(3.416)\end{array}$ & $\begin{array}{r}-22.193 \\
(2.726)\end{array}$ & $\begin{array}{r}-14.345 \\
(2.670)\end{array}$ \\
\hline $\begin{array}{l}\text { Threshold } \\
\text { (\$US Thous.) }\end{array}$ & $\begin{array}{l}140.173^{\mathrm{a}} \\
(18.879)\end{array}$ & $\begin{array}{l}117.921^{\mathrm{a}} \\
(14.974)\end{array}$ & $\begin{array}{r}95.427^{\mathrm{a}} \\
(15.693)\end{array}$ & $\begin{array}{l}147.755^{a} \\
(20.318)\end{array}$ & $\begin{array}{l}120.871^{a} \\
(15.457)\end{array}$ & $\begin{array}{r}87.024^{\mathrm{a}} \\
(14.323)\end{array}$ \\
\hline $\begin{array}{l}\ln \left(G N P_{i} G N P_{j}\right) \\
(1980)\end{array}$ & $\begin{array}{r}1.073^{\mathrm{a}} \\
(0.041)\end{array}$ & $\begin{array}{c}0.906^{\mathrm{a}} \\
(0.028)\end{array}$ & $\begin{array}{r}0.897^{\mathrm{a}} \\
(0.027)\end{array}$ & $\begin{array}{r}0.995^{\mathrm{a}} \\
(0.037)\end{array}$ & $\begin{array}{r}0.954^{\mathrm{a}} \\
(0.027)\end{array}$ & $\begin{array}{r}0.892^{\mathrm{a}} \\
(0.027)\end{array}$ \\
\hline $\begin{array}{l}\ln \left(P G N P_{i} P G N P_{j}\right. \\
)(1980)\end{array}$ & $\begin{array}{r}0.367^{\mathrm{a}} \\
(0.051)\end{array}$ & $\begin{array}{r}0.478^{\mathrm{a}} \\
(0.035)\end{array}$ & $\begin{array}{r}0.516^{\mathrm{a}} \\
(0.036)\end{array}$ & $\begin{array}{r}0.377^{\mathrm{a}} \\
(0.046)\end{array}$ & $\begin{array}{r}0.483^{\mathrm{a}} \\
(0.035)\end{array}$ & $\begin{array}{r}0.527^{\mathrm{a}} \\
(0.036)\end{array}$ \\
\hline $\ln (D I S T A N C E)$ & $\begin{array}{l}-1.430^{\mathrm{a}} \\
(0.111)\end{array}$ & $\begin{array}{l}-1.129^{a} \\
(0.086)\end{array}$ & $\begin{array}{l}-0.875^{a} \\
(0.082)\end{array}$ & $\begin{array}{l}-1.281^{\mathrm{a}} \\
(0.102)\end{array}$ & $\begin{array}{l}-1.209^{a} \\
(0.084)\end{array}$ & $\begin{array}{l}-0.843^{\mathrm{a}} \\
(0.083)\end{array}$ \\
\hline $\ln (R E M O T E)$ & $\begin{array}{r}1.937^{\mathrm{a}} \\
(0.219)\end{array}$ & $\begin{array}{r}0.626^{\mathrm{a}} \\
(0.170)\end{array}$ & $\begin{array}{c}0.235 \\
(0.158)\end{array}$ & $\begin{array}{l}1.519^{a} \\
(0.196)\end{array}$ & $\begin{array}{r}0.724^{\mathrm{a}} \\
(0.162)\end{array}$ & $\begin{array}{c}0.193 \\
(0.160)\end{array}$ \\
\hline$A D J A C E N T$ & $\begin{array}{c}0.051 \\
(0.353)\end{array}$ & $\begin{array}{r}0.519^{c} \\
(0.272)\end{array}$ & $\begin{array}{r}0.648^{b} \\
(0.276)\end{array}$ & $\begin{array}{c}0.127 \\
(0.323)\end{array}$ & $\begin{array}{c}0.375 \\
(0.288)\end{array}$ & $\begin{array}{r}0.705^{\mathrm{b}} \\
(0.281)\end{array}$ \\
\hline$E E C$ & $\begin{array}{l}-0.349 \\
(0.227)\end{array}$ & $\begin{array}{l}-0.058 \\
(0.159)\end{array}$ & $\begin{array}{l}-0.016 \\
(0.147)\end{array}$ & $\begin{array}{l}-0.479^{b} \\
(0.205)\end{array}$ & $\begin{array}{l}-0.097 \\
(0.161)\end{array}$ & $\begin{array}{c}0.024 \\
(0.149)\end{array}$ \\
\hline EFTA & $\begin{array}{l}-0.642 \\
(0.410)\end{array}$ & $\begin{array}{c}0.232 \\
(0.218)\end{array}$ & $\begin{array}{r}0.435^{\mathrm{b}} \\
(0.217)\end{array}$ & $\begin{array}{l}-0.435 \\
(0.306)\end{array}$ & $\begin{array}{c}0.301 \\
(0.209)\end{array}$ & $\begin{array}{r}0.456^{\mathrm{b}} \\
(0.222)\end{array}$ \\
\hline$L A N G U A G E$ & $\begin{array}{c}0.213 \\
(0.474)\end{array}$ & $\begin{array}{c}0.173 \\
(0.372)\end{array}$ & $\begin{array}{l}-0.238 \\
(0.279)\end{array}$ & $\begin{array}{c}0.176 \\
(0.443)\end{array}$ & $\begin{array}{c}0.102 \\
(0.365)\end{array}$ & $\begin{array}{l}-0.187 \\
(0.282)\end{array}$ \\
\hline COLOTIE & $\begin{array}{r}0.562^{\mathrm{b}} \\
(0.235)\end{array}$ & $\begin{array}{c}0.861^{\mathrm{a}} \\
(0.175)\end{array}$ & $\begin{array}{r}1.176^{\mathrm{a}} \\
(0.165)\end{array}$ & $\begin{array}{r}0.594^{\mathrm{a}} \\
(0.211)\end{array}$ & $\begin{array}{r}0.838^{a} \\
(0.176)\end{array}$ & $\begin{array}{r}1.183^{\mathrm{a}} \\
(0.166)\end{array}$ \\
\hline $\begin{array}{c}\text { CHINPOP * } \\
(1-S E A S I A 2)\end{array}$ & $\begin{array}{l}243.032^{\mathrm{a}} \\
(51.061)\end{array}$ & $\begin{array}{r}255.152^{\mathrm{a}} \\
(35.291)\end{array}$ & $\begin{array}{l}308.521^{\mathrm{a}} \\
(50.631)\end{array}$ & $\begin{array}{r}232.676^{a} \\
(44.882)\end{array}$ & $\begin{array}{r}253.969^{\mathrm{a}} \\
(35.718)\end{array}$ & $\begin{array}{l}315.053^{\mathrm{a}} \\
(51.165)\end{array}$ \\
\hline $\begin{array}{l}\text { CHINPOP * } \\
\text { SEASIA2 }\end{array}$ & $\begin{array}{r}3.613^{\mathrm{a}} \\
(1.061)\end{array}$ & $\begin{array}{r}4.688^{a} \\
(0.855)\end{array}$ & $\begin{array}{c}5.894^{\mathrm{a}} \\
(0.906)\end{array}$ & $\begin{array}{c}3.624^{\mathrm{a}} \\
(1.031)\end{array}$ & $\begin{array}{r}4.746^{\mathrm{a}} \\
(0.809)\end{array}$ & $\begin{array}{r}5.969^{\mathrm{a}} \\
(0.916)\end{array}$ \\
\hline Log Likelihood & -16257.9 & -16769.1 & -18418.9 & -17233.5 & -16360.3 & -18314.7 \\
\hline
\end{tabular}

Maximum likelihood estimation of threshold Tobit model.

Eicker-White standard errors in parentheses. Number of observations $=1595$.

${ }^{a}$ Significant at one percent level. ${ }^{b}$ Significant at five percent level. ${ }^{c}$ Significant at ten percent level. 
Table 5

Dependent Variable: Log of 1990 Bilateral Trade in Organized Exchange, Reference Priced, and Differentiated Commodities

Conservative aggregation

Liberal aggregation

\begin{tabular}{|c|c|c|c|c|c|c|}
\hline Variable & Org. & Ref. & Dif. & Org. & Ref. & Dif. \\
\hline Intercept & $\begin{array}{r}-43.887 \\
(3.630)\end{array}$ & $\begin{array}{r}-25.220 \\
(2.636)\end{array}$ & $\begin{array}{r}-18.368 \\
(2.527)\end{array}$ & $\begin{array}{r}-37.199 \\
(3.297)\end{array}$ & $\begin{array}{c}-25.969 \\
(2.591)\end{array}$ & $\begin{array}{r}-18.006 \\
(2.551)\end{array}$ \\
\hline $\begin{array}{l}\text { Threshold } \\
\text { (\$US Thous.) }\end{array}$ & $\begin{array}{l}106.761^{\mathrm{a}} \\
(14.287)\end{array}$ & $\begin{array}{l}137.012^{\mathrm{a}} \\
(19.857)\end{array}$ & $\begin{array}{l}123.508^{a} \\
(21.723)\end{array}$ & $\begin{array}{l}130.879^{a} \\
(17.346)\end{array}$ & $\begin{array}{l}120.586^{\mathrm{a}} \\
(17.730)\end{array}$ & $\begin{array}{l}115.979^{a} \\
(19.810)\end{array}$ \\
\hline $\begin{array}{l}\ln \left(G N P_{i} G N P_{j}\right) \\
(1990)\end{array}$ & $\begin{array}{r}1.035^{\mathrm{a}} \\
(0.035)\end{array}$ & $\begin{array}{r}0.960^{\mathrm{a}} \\
(0.024)\end{array}$ & $\begin{array}{r}0.975^{\mathrm{a}} \\
(0.024)\end{array}$ & $\begin{array}{r}0.983^{\mathrm{a}} \\
(0.032)\end{array}$ & $\begin{array}{r}0.977^{\mathrm{a}} \\
(0.024)\end{array}$ & $\begin{array}{r}0.981^{\mathrm{a}} \\
(0.024)\end{array}$ \\
\hline $\begin{array}{l}\ln \left(P G N P_{i} P G N P_{j}\right. \\
)(1990)\end{array}$ & $\begin{array}{r}0.150^{\mathrm{a}} \\
(0.040)\end{array}$ & $\begin{array}{r}0.216^{\mathrm{a}} \\
(0.026)\end{array}$ & $\begin{array}{r}0.267^{\mathrm{a}} \\
(0.026)\end{array}$ & $\begin{array}{r}0.167^{\mathrm{a}} \\
(0.036)\end{array}$ & $\begin{array}{r}0.207^{\mathrm{a}} \\
(0.026)\end{array}$ & $\begin{array}{r}0.279^{\mathrm{a}} \\
(0.026)\end{array}$ \\
\hline $\ln (D I S T A N C E)$ & $\begin{array}{l}-1.333^{\mathrm{a}} \\
(0.106)\end{array}$ & $\begin{array}{l}-0.941^{\mathrm{a}} \\
(0.083)\end{array}$ & $\begin{array}{l}-0.779^{a} \\
(0.084)\end{array}$ & $\begin{array}{l}-1.182^{\mathrm{a}} \\
(0.099)\end{array}$ & $\begin{array}{l}-1.001^{\mathrm{a}} \\
(0.083)\end{array}$ & $\begin{array}{l}-0.783^{\mathrm{a}} \\
(0.085)\end{array}$ \\
\hline $\ln (R E M O T E)$ & $\begin{array}{l}2.139^{a} \\
(0.207)\end{array}$ & $\begin{array}{r}0.982^{\mathrm{a}} \\
(0.157)\end{array}$ & $\begin{array}{r}0.499^{\mathrm{a}} \\
(0.153)\end{array}$ & $\begin{array}{l}1.771^{\mathrm{a}} \\
(0.190)\end{array}$ & $\begin{array}{r}1.035^{\mathrm{a}} \\
(0.154)\end{array}$ & $\begin{array}{r}0.455^{\mathrm{a}} \\
(0.155)\end{array}$ \\
\hline$A D J A C E N T$ & $\begin{array}{r}0.608^{c} \\
(0.338)\end{array}$ & $\begin{array}{r}0.852^{\mathrm{a}} \\
(0.272)\end{array}$ & $\begin{array}{r}0.921^{\mathrm{a}} \\
(0.276)\end{array}$ & $\begin{array}{r}0.656^{\mathrm{b}} \\
(0.313)\end{array}$ & $\begin{array}{r}0.745^{\mathrm{a}} \\
(0.274)\end{array}$ & $\begin{array}{r}0.964^{\mathrm{a}} \\
(0.280)\end{array}$ \\
\hline$E E C$ & $\begin{array}{l}-0.045 \\
(0.225)\end{array}$ & $\begin{array}{c}0.277 \\
(0.172)\end{array}$ & $\begin{array}{c}0.267 \\
(0.165)\end{array}$ & $\begin{array}{l}-0.050 \\
(0.211)\end{array}$ & $\begin{array}{c}0.212 \\
(0.170)\end{array}$ & $\begin{array}{c}0.265 \\
(0.167)\end{array}$ \\
\hline EFTA & $\begin{array}{l}-0.370 \\
(0.443)\end{array}$ & $\begin{array}{c}0.241 \\
(0.206)\end{array}$ & $\begin{array}{c}0.365 \\
(0.233)\end{array}$ & $\begin{array}{c}0.011 \\
(0.321)\end{array}$ & $\begin{array}{c}0.245 \\
(0.194)\end{array}$ & $\begin{array}{c}0.364 \\
(0.241)\end{array}$ \\
\hline$L A N G U A G E$ & $\begin{array}{r}0.982^{\mathrm{b}} \\
(0.443)\end{array}$ & $\begin{array}{r}1.322^{\mathrm{a}} \\
(0.340)\end{array}$ & $\begin{array}{c}0.404 \\
(0.321)\end{array}$ & $\begin{array}{r}0.801^{c} \\
(0.418)\end{array}$ & $\begin{array}{r}1.477^{\mathrm{a}} \\
(0.342)\end{array}$ & $\begin{array}{c}0.376 \\
(0.320)\end{array}$ \\
\hline COLOTIE & $\begin{array}{c}0.300 \\
(0.213)\end{array}$ & $\begin{array}{c}0.390^{\mathrm{b}} \\
(0.153)\end{array}$ & $\begin{array}{r}0.959^{\mathrm{a}} \\
(0.152)\end{array}$ & $\begin{array}{r}0.415^{b} \\
(0.194)\end{array}$ & $\begin{array}{c}0.309^{\mathrm{b}} \\
(0.154)\end{array}$ & $\begin{array}{r}0.986^{\mathrm{a}} \\
(0.156)\end{array}$ \\
\hline $\begin{array}{l}\text { CHINPOP * } \\
(1-S E A S I A 2)\end{array}$ & $\begin{array}{l}96.502^{\mathrm{a}} \\
(22.872)\end{array}$ & $\begin{array}{c}98.156^{\mathrm{a}} \\
(17.057)\end{array}$ & $\begin{array}{l}104.401^{\mathrm{a}} \\
(13.783)\end{array}$ & $\begin{array}{r}83.357^{\mathrm{a}} \\
(21.696)\end{array}$ & $\begin{array}{r}99.795^{\mathrm{a}} \\
(17.075)\end{array}$ & $\begin{array}{l}111.068^{a} \\
(14.268)\end{array}$ \\
\hline $\begin{array}{l}\text { CHINPOP * } \\
\text { SEASIA2 }\end{array}$ & $\begin{array}{c}1.833 \\
(1.337)\end{array}$ & $\begin{array}{r}2.931^{\mathrm{a}} \\
(0.695)\end{array}$ & $\begin{array}{c}4.755^{\mathrm{a}} \\
(0.879)\end{array}$ & $\begin{array}{c}2.098^{c} \\
(1.247)\end{array}$ & $\begin{array}{r}2.777^{\mathrm{a}} \\
(0.675)\end{array}$ & $\begin{array}{r}4.904^{\mathrm{a}} \\
(0.900)\end{array}$ \\
\hline Log Likelihood & -17283.9 & -18450.3 & -20067.6 & -18184.3 & -18328.4 & -19866.1 \\
\hline
\end{tabular}

Maximum likelihood estimation of threshold Tobit model.

Eicker-White standard errors in parentheses. Number of observations $=1652$.

${ }^{a}$ Significant at one percent level. ${ }^{b}$ Significant at five percent level. ${ }^{\mathrm{c}}$ Significant at ten percent level. 
Table 6

Percentage Increase in Bilateral Trade Attributable to Ethnic Chinese Networks

\begin{tabular}{|c|c|c|c|c|c|c|c|}
\hline & & \multicolumn{3}{|c|}{ Conservative aggregation } & \multicolumn{3}{|c|}{ Liberal aggregation } \\
\hline & & Org. & Ref. & Dif. & Org. & Ref. & Dif. \\
\hline & $S E A S I A 2=0$ & 4.0 & 4.2 & 5.1 & 3.9 & 4.2 & 5.3 \\
\hline \multicolumn{8}{|l|}{1980} \\
\hline & $S E A S I A 2=1$ & 113.5 & 167.5 & 244.5 & 114.0 & 170.8 & 250.0 \\
\hline \multirow{2}{*}{1990} & $S E A S I A 2=0$ & 2.6 & 2.7 & 2.9 & 2.3 & 2.7 & 3.0 \\
\hline & $S E A S I A 2=1$ & 43.9 & 78.9 & 157.0 & 51.7 & 73.5 & 164.7 \\
\hline
\end{tabular}

All figures are computed using the formula $100\left[\exp \left(\psi_{k}\right.\right.$ CHINPOP $)$ - 1], where the values of $\psi_{k}$ are taken from Tables 4 and 5 and the values of $C H I N P O P$ are the means given in footnote 9. 
Table 7

Impact of Ethnic Chinese Networks for Country Pairs Excluding and Including China

\begin{tabular}{|c|c|c|c|c|c|c|c|}
\hline & & \multicolumn{3}{|c|}{ Conservative aggregation } & \multicolumn{3}{|c|}{ Liberal aggregation } \\
\hline & & Org. & Ref. & Dif. & Org. & Ref. & Dif. \\
\hline \multirow{3}{*}{1980} & $\begin{array}{l}\text { CHINPOP* } \\
(1-S E A S I A 2) * \\
(1-C H I N A)\end{array}$ & $\begin{array}{l}294.652^{a} \\
(70.718)\end{array}$ & $\begin{array}{l}302.812^{\mathrm{a}} \\
(49.972)\end{array}$ & $\begin{array}{l}404.503^{a} \\
(68.625)\end{array}$ & $\begin{array}{l}287.765^{a} \\
(62.845)\end{array}$ & $\begin{array}{l}305.930^{\mathrm{a}} \\
(49.666)\end{array}$ & $\begin{array}{l}410.149^{a} \\
(69.616)\end{array}$ \\
\hline & $\begin{array}{l}\text { CHINPOP * } \\
\text { SEASIA2* } \\
(1-C H I N A)\end{array}$ & $\begin{array}{r}4.037^{\mathrm{a}} \\
(1.572)\end{array}$ & $\begin{array}{c}5.396^{\mathrm{a}} \\
(1.110)\end{array}$ & $\begin{array}{c}6.850^{\mathrm{a}} \\
(1.149)\end{array}$ & $\begin{array}{c}4.089^{a} \\
(1.546)\end{array}$ & $\begin{array}{r}5.448^{\mathrm{a}} \\
(1.024)\end{array}$ & $\begin{array}{r}6.929^{a} \\
(1.164)\end{array}$ \\
\hline & $\begin{array}{l}\text { CHINPOP* } \\
\text { CHINA }\end{array}$ & $\begin{array}{c}2.894^{\mathrm{a}} \\
(0.946)\end{array}$ & $\begin{array}{c}3.524^{\mathrm{a}} \\
(1.047)\end{array}$ & $\begin{array}{r}4.286^{\mathrm{a}} \\
(1.082)\end{array}$ & $\begin{array}{c}2.837^{\mathrm{a}} \\
(0.920)\end{array}$ & $\begin{array}{r}3.588^{\mathrm{a}} \\
(0.975)\end{array}$ & $\begin{array}{r}4.355^{\mathrm{a}} \\
(1.104)\end{array}$ \\
\hline \multirow{3}{*}{1990} & $\begin{array}{l}\text { CHINPOP* } \\
(1-S E A S I A 2) * \\
(1-C H I N A)\end{array}$ & $\begin{array}{l}121.055^{a} \\
(18.771)\end{array}$ & $\begin{array}{l}102.283^{\mathrm{a}} \\
(17.899)\end{array}$ & $\begin{array}{l}117.585^{a} \\
(19.191)\end{array}$ & $\begin{array}{l}106.147^{\mathrm{a}} \\
(15.817)\end{array}$ & $\begin{array}{l}109.605^{a} \\
(16.807)\end{array}$ & $\begin{array}{l}123.784^{\mathrm{a}} \\
(19.859)\end{array}$ \\
\hline & $\begin{array}{l}\text { CHINPOP* } \\
\text { SEASIA2* } \\
(1-C H I N A)\end{array}$ & $\begin{array}{c}1.546 \\
(1.878)\end{array}$ & $\begin{array}{r}3.282^{\mathrm{a}} \\
(0.991)\end{array}$ & $\begin{array}{r}5.390^{\mathrm{a}} \\
(1.382)\end{array}$ & $\begin{array}{c}1.929 \\
(1.756)\end{array}$ & $\begin{array}{r}3.126^{\mathrm{a}} \\
(0.985)\end{array}$ & $\begin{array}{r}5.556^{\mathrm{a}} \\
(1.415)\end{array}$ \\
\hline & $\begin{array}{l}\text { CHINPOP* } \\
\text { CHINA }\end{array}$ & $\begin{array}{c}2.277 \\
(1.561)\end{array}$ & $\begin{array}{c}2.452^{\mathrm{a}} \\
(0.721)\end{array}$ & $\begin{array}{c}3.818^{\mathrm{a}} \\
(0.662)\end{array}$ & $\begin{array}{c}2.356 \\
(1.464)\end{array}$ & $\begin{array}{c}2.287^{\mathrm{a}} \\
(0.624)\end{array}$ & $\begin{array}{c}3.946^{\mathrm{a}} \\
(0.693)\end{array}$ \\
\hline
\end{tabular}

Notes: see Tables 4 and 5. 